\title{
Analisis Faktor Hambatan Bisnis Online Terhadap Batik Tulis Sendang Agung
}

\author{
Sabilar Rosyad, Hery Suprapto \\ Fakultas Ekonomi, Universitas Islam Lamongan, Indonesia \\ Email corresponding author: rosyadabil4@unisla.ac.id
}

\begin{abstract}
ABSTRAK
Penelitian ini memfokuskan permasalahan pada bagaimana analisis hambatan bisnis online bagi Batik Tulis Sendang Agung. Teori yang digunakan dalam penelitian ini adalah Teori Uses and Gratifications. Metode penelitian adalah metode penelitian kualitatif. Informan yang ditetapkan adalah 5 informan. Teknik pengumpulan data yang digunakan dalam penelitian ini adalah wawancara terstruktur secara langsung.hasil penelitian yang ditemukan adalah masalah keterlambatan pengiriman dari supplyer. Solusi : Pembeli menyatakan estimasi waktu pengiriman serta kemungkinan keterlambatan pengiriman.. Masalah barang tidak sesuai ekspektasi pembeli. Solusi: Foto promosi suatu produk, khususnya produk batik, lebih baik untuk menggunakan model sebagai foto promosi, karena lebih realistis dibandingkan foto promosi yang tidak menggunakan model. Masalah pengiriman tidak sesuai dengan alamat pembeli. Solusi: Jika seseorang ingin membeli suatu barang secara online, hendaknya mereka mempelajari alamat lengkap tujuan pengiriman terlebih dahulu, untuk menghindari kesalahan pengiriman oleh pembeli. Masalah penipuan/barang tidak dikirim. Solusi: Mempelajari kinerja penjual online melalui respon-respon pelanggan yang biasanya tertera di halaman promosi penjual online. Ini juga dapat digunakan oleh penjual bisnis online, untuk menyediakan tempat bagi para pembeli untuk memberi respon yang dapat dibaca secara umum. Karena dengan respon-respon pembeli yang baik, dapat meningkatkan reputasi penjual online hingga lebih terpercaya. Yang menjadi saran atau masukan dalam penelitian ini adalah : penelitian ini masih perlu dilakukan pengembangan, oleh karena itu untuk penelitian mendatang terhadap e- commerce perlu dikaji lebih lanjut mengenai analisis hambatan bisnis online.kemudian untuk masyarakat, Khususnya para pemilik usaha batik sendang agung, dapat mengkaji hasil penelitian ini sebagai pembelajaran sebelum melakukan bisnis online, baik itu sebagai penjual, reseller, maupun pembeli.
\end{abstract}

Kata Kunci: Analisis, Hambatan, Bisnis Online

\section{PENDAHULUAN}

Perkembangan internet menyebabkan terbentuknya sebuah dunia baru yang lazim disebut dunia maya. Di dunia maya ini setiap individu memiliki hak dan kemampuan untuk berintraksi dengan individu lain tanpa batasan apapun yang dapat menghalanginya. Globalisasi yang sempurna sebenarnya telah berjalan di dunia maya menghubungkan seluruh komunitas digital. Dari seluruh aspek kehidupan manusia yang terkena dampak kehadiran internet, sektor bisnis merupakan sektor yang paling merasakannya. Pertumbuhan bisnis semakin cepat 
- Melalui E-commerce, untuk pertama kalinya seluruh manusia di muka bumi memiliki kesempatan dan peluang yang sama agar dapat bersaing dan berhasil bersaing di dunia maya.

Internet adalah sistem informasi global berbasis komputer. Bergaul dengan internet sama juga bergaul dengan komputer. Internet tidak akan pernah ada tanpa komputer. Ibarat kapal tanpa nahkoda, pastinya tidak mampu berjalan. Begitu juga dengan internet; tanpa adanya komputer kita tidak bisa mengakses internet. Untuk mengakses internet kita hanya membutuhkan seperangkat komputer, modem, dan saluran telpon. Bahkan saat ini tidak perlu mempergunakan jaringan telpon, cukup dengan menggunakan wireless internet.

Adapun fasilitas dalam internet yaitu E-mail (surat elektronik), Bulletin Board System (BBS), File Transfer Protocol (FTP), Information Browsing (gopher), Remote Login (Telnet), Advanced Browsing (www), Automated Title Search, Komunikasi audio dan visual. Banyak perusahaan dan organisasi kini telah menerapkan teknologi berbasis internet, dunia web, dan sistem komunikasi nirkabel/wireless untuk mengubah bisnis mereka selama lebih dari 15 tahun sejak penciptaan situs web pertama (http://info.cern.ch) oleh Sir Tim Berners- Lee pada tahun 1991.

E-Business dan E-Commerce adalah area yang menarik untuk dikembangkan dan dipelajari karena banyak peluang dan tantangan baru muncul setiap tahun, bulan, dan bahkan setiap hari. Inovasi akan terus berkembang dengan adanya penemuan teknologi baru, model bisnis baru, dan pendekatan komunikasi baru. Sebagai contoh, Google berinovasi tanpa henti. Layanan telah berkembang jauh sejak tahun 1998. Miliaran halaman sekarang diindeks. Layanan lainnya seperti web mail, pay per click adverts (per klik iklan berbayar), analisis, dan social network (jaringan sosial), merupakan bagian dari penawaran.

Pertumbuhan e-commerce nampaknya akan berkembang terus seiring dengan makin memasyarakatnya jaringan global internet, bahkan beberapa pakar teknologi informasi memprediksi bahwa internet akan menjadi bagian sehari-hari masyarakat modern pada masa mendatang. Ini artinya mereka akan demikian kental berurusan dengan internet dalam segala hal termasuk membeli atau menjual barang dan jasa. Begitu pula perusahaan- perusahaan akan mengupayakan pelebaran pangsa pasarnya melalui jaringan internet sebagai strategi baru yang sangat global. Dengan kata lain e-commerce akan menjelma menjadi infrastruktur bisnis alternatif yang mumpuni pada era informasi kini dan mendatang (lkht- fhui.net).

E-commerce adalah lahan baru untuk membangkitkan dan mengeksploitasi bisnis yang mengutamakan efektifitas dalam pelaksanaannya. E-commerce menyelenggarakan transaksi bisnis melalui jaringan elektronik dengan sejumlah perbaikan terhadap kinerja bisnis tradisional. Sehingga akan tercipta wajah bisnis 
baru dengan unjuk kerja lebih baik: kualitas interaksi, kepuasan pelanggan dan efektifitas pembuatan keputusan.

Salah satu perusahaan yang telah sukses dengan menerapkan e-commerce adalah Amazon.com di Amerika, yang telah berhasil menjual buku dengan omzet jutaan dolar tanpa perlu memiliki gudang untuk menyimpan buku, membuka toko buku, apalagi menerbitkan buku (www.itcentre-komunitas teknologi informasi indonesia), Kemudian kesuksesan juga diraih Matahati Putra Prima tbk dengan menerapkan e- commerce. Perombakan struktur bisnis dan manajemen juga dilakukan Lippo untuk memperbaiki kinerja usaha PT. Matahari Putra Prima tbk. Lewat implementasi e- commerce B2B, dan meningkatkan kinerja implementasi sistem e-commerce B2B (Business to Business) yang sudah go live sejak tahun 1999 lalu. Saat ini matahari tercatat sudah berhubungan secara elektronis dengan pemasok besarnya seperti Martha Tilaar, Mustika Ratu, dan Nestle.

Saat ini, dengan bergabung kepada gateway indosat.com, para pemasok matahari bisa memangkas biaya administrasi pengadaan barang sebesar

$50 \%$. Angka ini berasal dari berkurangnya biaya pengiriman faks, pengarsipan, dan entry data. Jelasnya kalau sebelumnya biaya pengurusan per dokumen mencapai Rp. 5964, maka sesudah ecommerce B2B diterapkan, ongkosnya hanya Rp. 2854 per dokumen (www.wartaekonomi.com).

Kemudian dalam sebuah penelitian yang dilakukan di 27 perusahaan di Indonesia yang telah menerapkan e- commerce dengan meneliti motif dan manfaat yang dirasakan perusahaan dikatakan bahwa motif yang melandasi perusahaan terdorong menggunakan ecommerce yaitu Mengakses Pasar global sebesar 56\%, Mempromosikan produk sebesar 63\%, Membangun Merk sebesar 56\%, Mendekatkan dengan pelanggan sebesar $74 \%$, Membantu komunikasi lebih cepat dengan pelanggan sebesar 63\% dan Memuaskan pelanggan sebesar 56\% kemudian dari 27 perusahaan yang telah menerapkan e-commerce bahwasannya $30 \%$ diantaranya merasakan manfaat meningkatnya omzet penjualan. $25 \%$ merasakan manfaat peningkatan jumlah pelanggan, $16 \%$ perluasan jangkauan bisnis dan sarana promosi, $5 \%$ mendapatkan peluang terbukanya bisnis baru dan kepuasan pelanggan, serta $2 \%$ merasakan kemudahan hubungan relasi (www.spica almalia.wordpres).

Kenyataan ini membuktikan bahwa e-commerce memiliki peran penting dalam membantu meningkatkan omzet penjualan, efisiensi pada tenaga kerja dan seluruh biaya operasional yang perlu dikeluarkan untuk pembuatan produk dan pemasarannya. Makin ketatnya persaingan, mengharuskan dunia usaha Indonesia secara terus menerus melakukan efisiensi, meningkatkan kualitas produk, pelayanan serta inovasi baru. Efisiensi dilakukan secara total mulai dari 
perencanaan, proses produksi, pemasaran dan pendistribusian dengan menggunakan internet bisa

mengurangi biaya staf infrastruktur dan biaya lainnya yang biasanya harus dibayar oleh perusahaan tradisional. Bila perusahaan di Indonesia tidak mengubah cara bisnisnya maka sulit untuk bisa bersaing dengan perusahaan lain yang mampu menawarkan barang dan jasa yang sama dengan harga yang lebih murah.

Telah dikatakan bahwa berbisnis di internet telah berpengaruh besar dalam berbagai jenis bisnis. Begitu juga dengan real esatate dan industri perjalanan (travel) berkembang secara dramatis dengan semakin banyaknya konsumen yang berbelanja melalui internet, karena kemudahan serta keuntungan besar yang ditawarkan cara bisnis baru ini, banyak perusahaan yang membawa bisnisnya kearah online.

Dengan adanya tiga kategori di atas, dapat memudahkan para pelaku bisnis untuk melakukan sasaran yang akan dituju. Dengan demikian, "yang harus diingat dalam melangsungkan aktivitas bisnis e-commerece yaitu: adanya proses baik penjualan maupun pembelian secara elektronik adanya konsumen atau perusahaan dan adanya jaringan penggunaan komputer secara online untuk melakukan transaksi bisnis". Di samping itu, bisnis e-commerce mempunyai beberapa keuntungan antara lain yaitu: "dapat memperluas jaringan mitra bisnis, jangkauan pemasaran menjadi semakin luas, aman secara fisik, efektif, efisien, dan fleksibel, selain itu terdapat kekurangan dalam bisnis e-commerce ini antara lain: meningkatkan individualisme, terkadang menimbulkan kekecewaan dan tidak manusiawi. Dalam mendapatkan kepercayaan dalam e-commerce, ada beberapa prinsip yang harus dipenuhi, antara lain keterbukaan (business practice disclosure) yaitu akan melakukan transaksi sesuai dengan yang dijanjikan. Integritas transaksi (transaction integrity) yaitu tagihan yang sesuai dengan transaksi. Dan juga perlindungan terhadap informasi (information protection) yaitu penjagaan informasi agar tidak jatuh ke pihak yang tidak berkaitan dengan bisnisnya.

Peningkatan transaksi menggunakan e-commerce oleh perusahaan merupakan indikasi bahwa manajemen memiliki komitmen terhadap pemanfaatan cara baru. Atau lebih tepat digambarkan sebagai suatu komitmen untuk memanfaatkan e-commerce di dalam pengembangan perusahaan. Selama ini, sistem penjualan yang digunakan oleh perusahaan hanya bersifat manual dan secara tertulis, yang tidak jarang cenderung menyesatkan. Dengan adanya layanan jasa berupa e-commerce yang dapat secara cepat dapat dinikmati oleh pelanggan maupun perusahaan sendiri, maka segala layanan yang diinginkan oleh para pelanggan dapat segera ditindak lanjuti dengan secepat mungkin, sehingga perusahaan tersebut akan mampu memberikan palayanan yang terbaik dan tercepat bagi para pelanggan. E-commerce sering menunggangi situs maupun media social yang sering dikunjungi konsumen. 
Sebagai media sosial yang paling popular digunakan dikalangan mahasiswa Unsrat saat ini, Facebook, Instagram, dan Blackberry Messenger sering menjadi jembatan utama dalam transaksi e-commerce. Sebagai salah satu konsumen e-commerce, dalam hal ini penulis mengamati bahwa cukup banyak mahasiswa Unsrat yang sering melakukan transaksi e-commerce, baik sebagai penjual, reseller, distributor, maupun konsumen.

\section{METODE PENELITIAN}

Berdasarkan jenisnya penelitian ini merupakan penelitian kualitatif, Jika penelitian kuantitatif pengumpulan data yang banyak di gunakan untuk pengambilan kesimpulan yang mantap, penelitian kualitatif menggunakan berbagai prosedur pengumpulan data dalam rangka menegaskan berbagai prosedur pengumpulan data dalam rangka menegaskan wawasan yang sedang di kembangkan dan menjamin kepercayaan data yang di kumpulkan (Suharsimi Arikunto, 2010:25). Penelitian ini bertujuan mengetahui hambatan-hambatan dalam bisnis online serta solusi yang sering dilakukan oleh para pelaku bisnis online, baik sebagai pembeli maupun penjual.

\section{Sumber Data}

Sumber data dalam penelitian ini dipilih dengan menggunakan metode purposive sampling, yakni responden diambil dari pemilik galeri/usaha batik dan konsumen yang sering melakukan transaksi dalam bisnis online, baik sebagai pembeli maupun penjual. Adapun yang menjadi responden dalam penelitian ini adalah :

Penjual bisnis online:

a) Subjek \#1. Sri Wahyuni. 53 tahun. pemilik usaha galeri batik SIDOMAKMUR.

b) Subjek \#2. Anis Fatul Nur Azizah. 29 tahun. pemilik usaha galeri batik Cahaya Utama. Sebagai reseller online yang memasarkan Batik.

Pembeli bisnis online:

a) Subjek \#3. M. Yanto. 36 tahun.

b) Subjek \#4. Puguh Cahyono. 42 tahun.

c) Subjek \#5. Budi Prayitno. 29 tahun

Wawancara dengan Subjek \#1 dan Subjek \#2 dilakukan di Tempat Galeri Batik di masing - masing subjek, pada tanggal 28 September 2020, dimulai pada pukul 09.15. Wawancara dengan Subjek \#3 dan \#4 dilakukan di Caffe Omah Lamongan pada tanggal 01 Oktober 2020, dimulai pada pukul 15.35. Wawancara dengan Subjek \#5 dilakukan di galeri batik sidomakmur pada tanggal 18 September 2020, dimulai pada pukul 12.00 . 


\section{Teknik Pengumpulan Data}

Pada penelitian ini pengumpulan data dilakukan dengan menggunakan metode metode wawancara terstruktur dan observasi. Alasan dipilihnya metode wawancara terstruktur dalam penelitian ini adalah karena didalam penelitian ini, informasi yang diperlukan adalah berupa kata-kata yang diungkapkan subjek secara langsung, sehingga dapat dengan jelas menggambarkan pengalaman subjek penelitian dalam bisnis online dan mewakili kebutuhan informasi dalam penelitian. Observasi adalah pengamatan dan pencatatan secara sistematik terhadap gejala yang tampak pada objek penelitian.

\section{Teknik Analisis Data}

Tahap menganalisis data adalah tahap yang paling penting dan menentukan dalam suatu penelitian. Data yang diperoleh selanjutnya dianalisis dengan tujuan menyederhanakan data kedalam bentuk yang lebih mudah dibaca. Analisis data merupakan upaya mencari dan menata secara sistematis catatan hasil observasi, wawancara dan dokumentasi, untuk meningkatkan pemahaman peneliti tentang temuan-temuan berdasarkan permasalahan yang diteliti. Analisis data menurut Patton adalah proses mengatur urutan data, mengorganisasikan kedalam suatu pola, kategori dan satuan urutan dasar. Dalam penelitian kualitatif, analisis dilakukan sepanjang penelitian berlangsung, sejak pengumpulan data dimulai, analisis data dilangsungkan secara terus meneus hingga pembuatan laporan penelitian. Laporan itu hendaknya merupakan penyajian data secara analisis dan deskriptif yang telah dikumpulkan dan ditafsirkan secara sistematis.

\section{TEMUAN DAN PEMBAHASAN}

\section{Temuan}

Dari hasil wawancara yang dilakukan terhadap kelima responden, didapat beberapa hambatan-hambatan dan solusi dalam bisnis online sebagai berikut:

a. Masalah keterlambatan pengiriman dari supplyer.

Solusi :

Subjek \#1 secara real (Benar) menyatakan estimasi waktu pengiriman serta kemungkinan keterlambatan pengiriman.

Hal ini bisa juga dapat menjadikan penyebab keterlambatan pengiriman seperti hambatan yang dialami subjek \#3. Dimana keterlambatan pengiriman dari supplyer, dapat memperpanjang waktu pengiriman dari penjual atau reseller kepada pembeli.

b. Masalah barang tidak sesuai ekspektasi pembeli.

Solusi: Subjek \#1 bernegosiasi dengan konsumen agar mencapai resolusi, yaitu mengembalikan uang konsumen dan barang yang dibeli (membatalkan transaksi). Subjek \#2 sebisa mungkin berusaha menampilkan foto promosi yang realistis. Subjek \#4 menyarankan untuk lebih mempercayai foto promosi yang menggunakan 
model, karena lebih realistis. Dari sini dapat disimpulkan bahwa foto promosi suatu produk, khususnya produk batik,

lebih baik untuk menggunakan model sebagai foto promosi, karena lebih realistis dibandingkan foto promosi yang tidak menggunakan model.

c. Masalah pengiriman tidak sesuai dengan alamat pembeli.

Solusi: Subjek \#2 menyatakan kalau pembeli bisnis online harus memberikan alamat yang jelas dan tepat.

Dari sini didapatkan bahwa jika seseorang ingin membeli suatu barang secara online, hendaknya ia mempelajari alamat lengkap tujuan pengiriman terlebih dahulu, untuk menghindari kesalahan pengiriman oleh pembeli.

d. Masalah penipuan/barang tidak dikirim.

Solusi: Subjek \#5 menyarankan untuk mempelajari kinerja penjual online melalui respon-respon pelanggan yang biasanya tertera di halaman promosi penjual online. Ini juga dapat digunakan oleh penjual bisnis online, untuk menyediakan tempat bagi para pembeli untuk memberi respon yang dapat dibaca secara umum. Karena dengan respon-respon pembeli yang baik, dapat meningkatkan reputasi penjual online hingga lebih terpercaya.

\section{Pembahasan}

Kualitas pelayanan berpengaruh signifikan terhadap keputusan konsumen. Dari hasil penelitian diketahui bahwa kualitas pelayanan memiliki pengaruh yang signifikan terhadap keputusan konsumen dalam menggunakan gas PGN kota Batam. Pelayanan merupakan kegiatan membantu dalam penyediaan segala sesuatu yang dibutuhkan oleh orang lain, termasuk didalamnya konsumen. Pelayanan yang baik tentu akan membantu konsumen dalam menyelesaikan permasalahan yang dialami dan membuat konsumen merasa dihargai.

Perusahaan sebagai penyedia produk/ jasa yang ditawarkan kepada masyarakat tentu harus memperhatikan pelayanan yang akan diberikan kepada konsumen. Perusahaan harus memberikan pelayanan yang berkualitas. Pelayanan dikatakan berkualitas apabila perusahaan memiliki karyawan yang berkualitas, perusahaan memiliki sarana dan prasarana yang lengkap, perusahaan bertanggungjawab kepada setiap pelanggan, memberikan pelayanan secara cepat dan tepat, perusahaan memiliki karyawan yang mampu berkomunikasi dengan baik, karyawan perusahaan harus memahami dan mengetauhi tentang produk yang ditawarkan kepada konsumen, memahami kebutuhan pelanggan.

Dari hasil kuisioner yang telah diberikan kepada responen, diketahui bahwa PGN telah memberikan pelayanan yang diharapkan oleh konsumen, karyawan perusahaan sangat membantu dalam penyelesaian keluhan pelanggan, perusahaan mengutamakan kepentingan konsumen, serta perusahaan telah memiliki teknologi yang baik dalam memberikan pelayanan. 
Hasil penelitian ini sejalan dengan penelitian yang dilakukan oleh (Mukti, 2015) yang menyatakan bahwa kualitas pelayanan berpengaruh signifikan terhadap keputusan konsumen.

Kualitas produk berpengaruh signifikan terhadap keputusan konsumen. Dari hasil penelitian, diketahui bahwa kualitas produk memiliki pengaruh signifikan terhadap keputusan konsumen dalam memutuskan untuk menggunakan gas PGN. kualitas produk menjadi faktor penentu tingkat kepuasan yang diperoleh konsumen setelah melakukan pembelian dan pemakaian terhadap suatu produk/ jasa. Produk dikatakan berkualitas apabila produk tersebut mampu melaksanakan fungsinya seperti daya tahan, keandalan, ketepatan, kemudahan operasi dan perbaikan serta atribut bernilai lainnya.

Dilihat dari hasil penelitian, kualitas produk memiliki pengaruh yang besar terhadap keputusan konsumen dalam mengambil keputusan untuk menggunakan gas PGN dengan nilai koefisien 0,280. Hal ini berarti, perusahaan harus tetap menjaga kualitas produk mereka agar konsumen tetap setia menggunakan produk.

Dari hasil kuisioner yang telah diberikan kepada responden, diketahui bahwa penggunaan gas PGN lebih irit sehingga dapat masyarakat dapat menghemat, masyarakat menyetujui jika dengan menggunakan gas PGN, masyarakat mendapatkan banyak kemudahan karena tidak perlu khawatir jika kehabisan gas seperti penggunaan pada gas tabung (LPG), penggunaan gas dapat digunakan dalam jangka waktu yang lama, dan konsumen juga mengakui jika dengan menggunakan gas PGN lebih aman.

Hasil penelitan ini sejalan dengan penelitian yang dilakukan oleh (Sunarto, 2015) yang menyatakan bahwa kualitas produk berpengaruh terhadap keputusan pembelian konsumen.

Kualitas Pelayanan dan Kualitas Produk Secara Simultan Berpengaruh Signifikan Terhadap Keputusan Konsumen. Dari hasil penelitian diketahui bahwa kualitas pelayanan dan kualitas produk mempengaruhi keputusan konsumen dalam menggunakan gas PGN. Kualitas pelayanan dan kualitas produk tentu harus menjadi perhatian penting bagi perusahaan sebagai penyedia produk. Produk dan pelayanan yang berkualitas menjadi penentu konsumen dalam memutuskan untuk melakukan pembelian.

Dari hasil kuisioner yang telah diberikan kepada responden, diketahui bahwa konsumen sudah memperoleh informasi yang cukup mengenai produk sebelum memutuskan untuk menggunakan gas PGN, konsumen tertarik dengan produk yang dihasilkan oleh PGN, konsumen memutuskan menggunakan gas PGN karena kelebihan dari produk tersebut yang tidak dimiliki oleh produk lain, dan produk gas yang dihasilkan oleh PGN adalah produk yang dibutuhkan konsumen. 


\section{KESIMPULAN DAN SARAN}

Dari hasil wawancara yang dilakukan terhadap kelima responden, didapat beberapa hambatan-hambatan dan solusi dalam bisnis online sebagai berikut:

1. Masalah keterlambatan pengiriman dari supplyer.

Solusi : Pembeli menyatakan estimasi waktu pengiriman serta kemungkinan keterlambatan pengiriman sehingga dapat mengakibatkan konsumen yang kecewa.

2. Masalah barang tidak sesuai ekspektasi pembeli. Solusi: Foto promosi suatu produk, khususnya produk batik, lebih baik untuk menggunakan model sebagai foto promosi, karena lebih realistis dibandingkan foto promosi yang tidak menggunakan model.

3. Masalah pengiriman tidak sesuai dengan alamat pembeli. Solusi: Jika seseorang ingin membeli suatu barang secara online, hendaknya mereka mempelajari alamat lengkap tujuan pengiriman terlebih dahulu, untuk menghindari kesalahan pengiriman oleh pembeli.

4. Masalah penipuan/barang tidak dikirim. Solusi: Mempelajari kinerja penjual online melalui respon-respon pelanggan yang biasanya tertera di halaman promosi penjual online.

Ini juga dapat digunakan oleh penjual bisnis online, untuk menyediakan tempat bagi para pembeli untuk memberi respon yang dapat dibaca secara umum. Karena dengan respon-respon pembeli yang baik, dapat meningkatkan reputasi penjual online hingga lebih terpercaya.

\section{DAFTAR PUSTAKA}

S Rosyad. 2018. Efektifitas dan Efisiensi Penerapan E-Commerce Pada PT. Wahana

Surya Plastik. Jpim (Jurnal Penelitian Ilmu Manajemen) 3 (1), 627-637

Suprapto P. 2009. Pengantar Teori dan Manajemen Komunikasi. Buku Kita. Jakarta. Indonesia.

Gabriel F. T.E Mingkid. R Paputungan. 2017. Analisis Hambatan Bisnis Online Bagi Mahasiswa Unsrat. e-journal "Acta Diurna" Volume VI. No. 2. Tahun 2017

Somad R, Priansa D.J. 2014. Manajemen Komunikasi: Mengembangkan Bisnis Berorientasi Pelanggan. Penerbit Alfabeta. Bandung. Indonesia.

West R, Turner L.H. 2008 Pengantar Telekomunikasi. Edisi 3. Buku 1. Salemba Humanika. Jakarta. Indonesia..

Daryanto, Rahardjo M. 2015 Teori Komunikasi. Gava Media. Indonesia.Yogyakarta.

Sutrisno M, Putranto H. 2005. Teori-Teori Kebudayaan. Kanisius. Yogyakarta. Indonesia.

Purwanto D. 2006. Komunikasi Bisnis. Edisi Ketiga. Erlangga. Jakarta. Indonesia.

Sumber lain : 
Wong J. Internet Marketing for Beginners. Elex Media Komputindo. Jakarta. Indonesia. 2010. Tersedia pada

URL:

https://books.google.co.id/books?id=qwdLnknAQC. Akses 18 Mei 2017. Suyanto M. Strategi Periklanan pada Perusahaan e-commerce Top Dunia. Andi Offset. Yogyakarta. Indonesia. 2003. Tersedia pada URL: https://books.google.co.id/books?id=VRVPbZ0SasC. Akses 18 Mei 2017.

Pawito. Penelitian Komunikasi Kualitatif. LkiS. Yogyakarta. Indonesia. 2008.

Tersedia pada URLhttps://books.google.co.id/books?id=UfM33NzcHJsC. Akses 18 Mei 2017.

Buddy S. Analisa Seluruh Industri Sektor Dan Semua Sub Sektor Saham di BEI

2015. BSK Capital. Jakarta. Indonesia. 2016. Tersedia pada URL : https://books.google.co.id/books/id=BBWuCwAAQBAI. Akses 18 Mei 2017.

Resi P.O., Berto W.M., L. Titah. Identifikasi Permasalahan Komplain pada E- commerce Menggunakan Metode Fishbone. Jurnal Sains dan Seni ITS.

2017. Vol. 6:1. Hal 37-41.

Wulandari F.M. Jual Beli Online yang Aman dan Sya'riah (Studi Terhadap Pandangan Pelaku Bisnis Online di Kalangan Mahasiswa dan Alumni Fakultas Syari'ah dan Hukum UIN Sunan Kalijaga). Jurusan Muamalat Fakultas Sya'riah dan Hukum Universitas Islam Negeri Sunan Kalijaga. Yogyakarta. 2015. 